\title{
ENGAGEMENT PEGAWAI GENERASI MILLENIAL: ANTARA GAYA KOMUNIKASI PIMPINAN DAN IKLIM ORGANISASI
}

\author{
Engagement of Millennial Employee : Between Leader Communication Style and \\ Organization Behavior
}

\author{
Bambang Kismanto \\ Kementerian Keuangan
}

\begin{abstract}
Employee engagement is important for all parts of human resources in an agency or company. Employees and leaders who are not engaged with the organization had a decrease in the level of work quality, a decrease in efficiency, inconsistencies in service, a decrease in initiatives to provide suggestions for organizational progress, and ultimately reduce the level of organizational performance. Thus it is necessary to explore the factors that can influence the level of employee engagement. Factors of leadership style and organizational climate are examined for their influence on the level of employee engagement in this study which is divided into three hypotheses. The research locus is in the Financial Education and Training Agency. Data analysis in this study was carried out using SPSS version 17.0 for windows.
\end{abstract}

Keywords: Engagement, leader communication style, organization behavior

ABSTRAK: Employee engagement penting bagi semua bagian dari sumber daya manusia di instansi atau perusahaan. Pegawai dan pimpinan yang tidak engaged mengalami penurunan tingkat kualitas kerja, penurunan efisiensi, inkonsistensi pelayanan, penurunan inisiatif untuk memberi saran bagi kemajuan organisasi, dan akhirnya menurunkan tingkat kinerja organisasi. Dengan demikian perlu digali faktor-faktor yang dapat mempengaruhi tingkat employee engagement tersebut. Faktor gaya komunikasi pimpinan dan iklim organisasi dikaji pengaruhnya terhadap tingkat employee engagement pada kajian ini yang dibagi menjadi tiga hipotesis. Lokus penelitian adalah di Badan Pendidikan dan Pelatihan Keuangan. Analisis data dalam penelitian ini dilakukan dengen menggunakan SPSS versi 18.0 for windows.

Kata kunci : Engagement, Gaya Komunikasi Kepemimpinan, Iklim Organisasi

\section{PENDAHULUAN}

Generasi Milenial saat ini menjadi generasi yang berperan dalam kelangsungan organisasi. Berdasarkan data Badan Pusat Statistik tahun 2016, dari total jumlah angkatan kerja di Indonesia yang mencapai 160 juta, hampir $40 \%$ di antaranya tergolong millennials sebesar 62,5 juta. Jumlah tersebut menjadi yang terbanyak kedua setelah generasi $X$ yang mencapai 69 juta, dan jauh di atas generasi baby boomers yang hanya tersisa 28,7 juta. Data tersebut menjukkan bahwa generasi millenial akan segera menjadi angkatan kerja terbesar di Indonesia. Jika sebagian besar pegawai di sebuah perusahaan atau di kantor instansi pemerintahan tidak engaged maka mengganggu stabilitas perusahaan atau instansi pemerintahan.

Dalam survey "Employee Engagement Among Millennials" yang dipublikasikan di website Marketeers, tanggal 27 Oktober 2017, dinyatakan terdapat $9 \%$ karyawan dari generasi millennial menolak terlibat/disengaged dengan perusahaan. Lebih besar lagi, yakni $66 \%$ tenaga kerja millennial cuma terlibat sebagian/partial-engaged. Tentunya mengkhawatirkan pagi perusahaan, sebab golongan ini bisa berpindah ke disengaged jika tidak segera dilakukan tindakan antisipasi. Menurut 
publikasi tersebut menyatakan bahwa Employee engagement merupakan komitmen karyawan, baik emosional maupun intelektual, untuk memberikan performa terbaiknya kepada perusahaan.

Masih menurut publikasi tersebut, fakta mencengangkan lainnya ditemukan bahwa hanya satu di antara empat millennials yang engaged, dan $64 \%$ engaged pasti akan bertahan setidaknya setahun ke depan. Sebaliknya, $60 \%$ millennials berencana mengundurkan diri apabila merasa disengaged dengan perusahaan yang sekarang mereka tempati. Karyawan yang engaged cenderung loyal dan bersedia bertahan dalam jangka waktu yang panjang. Tidak hanya bertahan, tetapi juga berkontribusi pada keuntungan perusahaan, dan bekerja secara produktif dan berkualitas.

Sementara, mereka yang partiallyengaged lebih fokus pada pengerjaan tugas, alias yang penting selesai. Selain itu, mereka ini hanya berorientasi pada gaji saja, atau istilah mereka "guwe kerjain, guwe digaji, guwe pulang". Kategori disengaged lebih berbahaya lagi karena menyebarkan pengaruh negatif, menampakkan ketidakpercayaan dan permusuhan, sudi menyabotase pekerjaan bahkan kemajuan perusahaan.

Karyawan yang engaged secara emosional akan mendedikasikan dirinya kepada organisasi dan secara penuh berpartisipasi di dalam pekerjaannya dengan antusias yang besar untuk kesuksesan dirinya dan atasan mereka, memberikan sesuatu yang lebih atas kontrak semula (Markos et al, 2010,). Penelitian mengindikasikan bahwa di Indonesia hanya sekitar 30 persen dari karyawan yang engaged secara aktif dengan sisa 70 persen lainnya menyibukkan diri namun tidak memberikan kontribusi yang cukup, baik secara individual maupun kolektif (Titus Amol, 2010).

Menurut Gallup Organization, Employee Engagement Index (EEI) memiliki implikasi yang signifikan terhadap kepuasan pelanggan, pertumbuhan yang berkelanjutan, kenaikan profit, kenaikan nilai saham, produktivitas dan retensi karyawan. Hal ini semakin membuktikan betapa pentingnya menumbuhkan engagement karyawan dalam suatu perusahaan. Menurut Papalexandris, dan Galanaki (2009, p365-385) employee engagement juga mempunyai hubungan dengan leadership.

Faktor lain yang sangat menentukan tingkat engaged bagi karyawan adalah iklim organisasi. Davis (1962), Organisasi yang baik adalah organisasi yang memiliki iklim yang didukung oleh kepribadian karyawan yang baik dan persepsi mereka terhadap prosedur organisasi. Liliweri (1997: 72 ) berpendapat bahwa iklim organisasi memiliki beberapa sub variabel yang antara lain praktik pengawasan,kohesi kelompok,variasi filosofi manajer, dan pribadi anggota/karyawan yang saling melengkapi. Menurut Tagiuri dan Litwin (dalam, Wirawan 2007) Iklim organisasi merupakan kualitas lingkungan internal organisasi yang secara relatif terus berlangsung, dialami oleh anggota organisasi, mempengaruhi perilaku mereka dan dapat dilukiskan dalam pengertian satu set karakteristik atau sifat organisasi. Stinger (Wirawan, 2007) mendefinisikan bahwa iklim organisasi sebagai koleksi dan pola lingkungan yang menentukan munculnya motivasi serta berfokus pada persepsi-persepsi yang masuk akal atau dapat dinilai, sehingga mempunyai pengaruh langsung terhadap kinerja anggota organisasi. Iklim organisasi adalah lingkungan manusia dimana para pegawai organisasi melakukan pekerjaannya. Iklim organisasi tidak dapat dilihat atau disentuh tetapi iklim ada seperti udara dalam suatu ruangan mengitari dan mempengaruhi segala hal yang terjadi dalam suatu organisasi (Davis 1996).

Istilah iklim organisasi (organizational climate) pertama kali diperkenalkan oleh Kurt Lewin pada tahun 1930-an. Beliau menghubungkan perilaku manusia dengan lingkungannya. Di dalam studi Lewin terkait dengan iklim psikologi (psychological climate). Kemudian istilah iklim organisasi dipakai oleh Tagiuri dan Litwin (1968) yang mengemukakan sejumlah istilah untuk melukiskan perilaku dalam hubungan dengan latar atau tempat (setting) dimana perilaku muncul: 
lingkungan (environment), lingkungan pergaulan (milieu), budaya (culture), suasana (atmosphere), situasi (situation), pola lapangan (field setting), pola perilaku (behavior setting), dan kondisi (conditions).

Berdasarkan uraian di atas, maka peneliti tertarik untuk meneliti mengenai hubungan antara gaya komunikasi pimpinan dan iklim organisasi terhadap tingkat engagement karyawan generasi millenial. Apa pengaruh gaya komunikasi pimpinan dan iklim organisasi terhadap tingkat keterlibatan (engagement) pegawai generasi millenial di lingkungan Kementerian Keuangan.

\section{TINJAUAN PUSTAKA}

\section{A. Generasi Milenial}

Generasi didefinisikan sebagai sekelompok orang berdasarkan identifikasi kelompok usia (tahun kelahiran) yang sama, termasuk kesamaan lokasi, dan kesamaan peristiwa kehidupan yang signifikan dan terjadi selama tahapan perkembangan kritikal dalam hidup seseorang sehingga membentuk cara pandang yang sama atas dunia yang dihadapi. Menurut Horovitz (2012) generasi millenial atau disebut juga generasi $Y$ adalah generasi yang lahir 1980 hingga awal 2000. Generasi Y sering menerapkan kreativitas serta berfokus pada pengembangan diri sehingga cenderung memilih pekerjaan yang menyenangkan bagi mereka dan cenderung berhura-hura (Femina, 2015).

Anantatmulia (2012) dalam Luntungan dkk (2014) menyebutkan karakteristik generasi millenial sangat dekat dengan teknologi. Masih menurut Anantatmulia, generasi $Y$ memiliki karakter ambisius, kepercayaan diri tinggi, multi tasking, independen, tidak mau bergantung pada orang lain maupun peraturan.

Generasi millennial disebut juga sebagai kelompok usia dari beberapa kelompok pembagian subkultur berdasarkan usia (Schiffman dan Kanuk, 2010). Pembagian generasi, atau yang biasa disebut generasi kohort (generational cohorts) merupakan salah satu hal yang perlu diperhatian dalam pengambilan keputusan pemasaran manajerial (Motta et al., 2008). Fore (2012) mengungkapkan bahwa generasi millennial lahir di antara tahun 1980 hingga 2000.

Generasi $Y$ tumbuh seiring
dengan banyak kejadian yang mengubah dunia, di antaranya berkembangnya komunikasi massa, serta internet. Generasi Y yang telah bekerja menunjukkan sikap yang senantiasa bertentangan dengan peraturan kantor. Namun, generasi ini boleh dipuji untuk energi dan semangat bekerjanya yang luar biasa (Tapscott, 1998).

Generasi $Y$ adalah generasi terbesar dalam sejarah dengan sekitar 79,8 juta anggota, melebihi jumlah generasi Baby Boomers (Robert Half International, 2008). Generasi $Y$ adalah generasi terbaru yang masuk dalam dunia kerja. Masuknya generasi $Y$ ke dunia kerja menimbulkan konflik antar generasi yang signifikan (Alch, 2000). Generasi lain menganggap generasi $Y$ adalah generasi yang sulit dipahami dan memiliki stereotip tersendiri. Ada banyak kesalahpahaman tentang generasi Y, Robert Half International (2008) melakukan studi bagaimana untuk merekrut dan mempertahankan karyawan generasi Y. Generasi Y telah diberi label sebagai generasi malas, menuntut banyak hal dan tidak tahu berterima kasih. Ini adalah mitos yang disalahtafsirkan oleh generasi yang lain yang tidak mengerti bagaimana pekerja generasi $Y$ berpikir. Oleh karena itu, sangat penting untuk membangun pemahaman tentang setiap generasi yang akan membantu untuk menjembatani perbedaan generasi, sebagai manfaat organisasi untuk merekrut dan mempertahankan anggota dari generasi terbaru di dunia kerja.

Generasi $Y$ dibesarkan dalam waktu yang tak menentu, yang membuat mereka menjadi generasi independent dan bergantung pada diri 
mereka sendiri, bukan pada orang lain untuk membantu mereka berhasil. Atkinson (2008) lebih lanjut menjelaskan dengan menggunakan sebuah literature review, survei, dan wawancara dengan anggota generasi $Y$ yang mayoritas dari mereka tumbuh dengan mengatakan segala sesuatu yang mereka ketahui dan keterbatasan pada diri mereka sendiri. Generasi Y juga telah dijuluki sebagai generasi yang paling dicari, karena mereka memiliki orang tua yang selalu terlibat dalam setiap aspek kehidupan mereka (Atkinson, 2008). Generasi $Y$ menganggap bahwa pekerjaan itu suatu yang menyenangkan dan akan melakukannya dengan penuh tanggungjawab tanpa tekanan. Para generasi $Y$ melakukan segalanya dengan seimbang, apabila jam kerja telah usai, maka usai juga yang mereka kerjakan, dan mereka sangatmembutuhkan waktu selain untuk bekerja. Seperti berlibur bersama keluarga dan teman-teman, karena dalam bekerja pun mereka lebih suka bekerja secara bersama (Lancaster \& Stillman, 2002; Ruch, 2000). Robert Half Internasional (2008) melakukan survei untuk menentukan bagaimana untuk merekrut dan mempertahankan generasi Y. Survei kuantitatif diberikan kepada 1.007 karyawan generasi $Y$ antara usia 21 dan 28. Studi menemukan bahwa generasi $Y$ mengharapkan untuk memiliki lebih banyak perubahan karir atau pekerjaan, fokus pada kehidupan pribadi atau keluarga, lebih banyak pengetahuan pada kemajuan teknologi, dan pendidikan lebih baik (Robert Half International, 2008). Penelitian ini juga menemukan bahwa generasi $Y$ menginginkan kebebasan, fleksibilitas dan kontrol atas pekerjaan mereka, dan diberi kreativitas untuk menyelesaikan pekerjaan mereka dengan pendekatan unik mereka sendiri. Mereka berharap pendidikan yang diliki sebagai percepatan kemajuan karir mereka.
Dari beberapa penelitian tersebut, berikut adalah ekspektasi kerja generasi $Y$ secara umum:

1. Penghargaan atas hasil kerja yang dicapai

2. Diberi kesempatan dalam setiap penangangan masalah yang ada

3. Mudahnya mengakses informasiinformasi terbaru melalui teknologi atau internet

4. Waktu kerja yang seimbang antara pekerjaan dan kehidupan pribadi.

5. Membutuhkan keleluasaan bekerja dimanapun dan kapanpun

\section{B. Keterikatan (Engagement)}

1. Pengertian Engagement

Employee engagement atau keterikatan karyawan adalah suatu kondisi, sikap atau perilaku positif seorang karyawan terhadap pekerjaan dan organisasinya yang ditandai dengan perasaan semangat (vigor), dedikasi (dedication) dan keasyikan (absorption) untuk tercapainya tujuan dan keberhasilan organisasi. Istilah employee engagement pertama kali diperkenalkan oleh William Khan pada tahun 1990, yang menyatakan bahwa engagement merupakan pemanfaatan diri anggota suatu organisasi untuk peran pekerjaan mereka dengan menggunakan dan mengekspresikan diri, baik secara fisik, kognitif dan emosional selama menjalankan peran mereka di dalam organisasi.

Keterikatan

karyawan terhadap pekerjaan maupun organisasi merupakan faktor paling penting keberhasilan dalam pengelolaan sumber daya manusia. Menurut Fisher, Schoenfeldt \& Shaw (2006 dalam Endres \& Smoak, 2008), sejumlah faktor yang dibutuhkan organisasi untuk menjadi kompetitif adalah sumber daya fisik, financial, daya pemasaran, dan sumber daya manusia. Di antara semuanya, faktor yang paling potensial menyediakan nilai kompetitif 
adalah sumber daya manusia dan pola pengelolaannya yang tepat (Endres \& Smoak, 2008). Jones, Ni \& Wilson (2009) juga menyatakan bahwa konstruk lain yang mendasarkan pada komitmen organisasi adalah employee engagement. Inti dari berbagai pemahaman dari employee engagement adalah "the expression of the self through work and other employee-role activities" (Jones \& Harter,2005 dalam Jones, dkk, 2009).

Menurut Hughes dan Rog (2008), employee engagement adalah hubungan emosional dan intelektual yang tinggi yang dimiliki oleh karyawan terhadap pekerjaannya, organisasi, manajer, atau rekan kerja yang memberikan pengaruh untuk menambah discretionary effort dalam pekerjaannya. Menurut Nurofia (2005), employee engagement merupakan antusiasme karyawan dalam bekerja yang terjadi karena karyawan mengarahkan energinya untuk bekerja yang selaras dengan prioritas strategic perusahaan. Antusiasme ini terbentuk karena karyawan merasa engage (feel engaged) sehingga berpotensi untuk menampilkan perilaku yang engaged. Perilaku yang engage memberikan dampak positif bagi organisasi yaitu peningkatan revenue. Menurut Robinson, Perryman dan Hayday (2004), employee engagement adalah sikap positif individu karyawan terhadap organisasi dan nilai organisasi. Seorang karyawan yang memiliki tingkat keterikatan tinggi pada organisasi memiliki pemahaman dan kepedulian terhadap lingkungan operasional organisasi, mampu bekerja sama untuk meningkatkan pencapaian unit kerja/organisasi melalui kerja sama antara individu karyawan dengan manajemen. Menurut Schaufeli dan Bakker (2004), employee engagement adalah pemikiran positif, yaitu pemikiran untuk menyelesaikan hal yang berhubungan dengan pekerjaan dan dikarakteristikkan dengan vigor (resiliensi energi dan mental ketika bekerja), dedication (berpartisipasi dalam pekerjaan mengalami rasa antusiasme dan tantangan), dan absorption (konsenterasi dan senang dalam bekerja).

Engagement mirip dengan kesetiaan. Menurut Rutledge (2009), keduanya sama- sama mengandung komitmen namun memiliki konteks berbeda. Kesetiaan atau loyalitas kerja merupakan komitmen jangka panjang, sementara komitmen engagement lebih bersifat pendek dan sementara. Tiga hal utama yang mewakili engagement adalah (a) perasaan tertarik; (b) memiliki komitmen; (c) bersemangat. Kalimat yang mewakili ketiga poin dalam engagement kurang lebih adalah; (a) "Saya mau melakukan pekerjaan ini!"; (b) "Saya akan menyelesaikan pekerjaan ini dengan professional dan sebaikbaiknya!”; (c) "Saya mencintai pekerjaan ini!".

Engagement atau bisa juga disebut sebagai work engagement merupakan kondisi yang positif, fulfillment, dan aktivitas mental dengan karakteristik semangat (penuh energi), dedikasi, dan absorption. Kondisi ini kurang lebih menggambarkan individu yang penuh energi dan memiliki resiliensi mental saat bekerja, bersungguh- sungguh dalam usaha dan persisten menghadapi kesulitan. Sementara dedikasi menggambarkan keterlibatan yang kuat dalam bekerja serta adanya pemaknaan, antusiasme, inspirasi, rasa bangga, dan merasakan tantangan di dalamnya. Terakhir, absorption menggambarkan kondisi individu yang penuh konsentrasi dan tidak merasakan berlalunya waktu dalam bekerja (Schaufeli \& Bakker dalam Bakker, Schaufeli, Leiter, \& Taris, 2008). 
Menurut Schaufeli dan Bakker (2008), karyawan yang memiliki engagement yang tinggi memiliki ciri-ciri yang dikenal dengan istilah 3S (Say, Stay dan Strive). Say, artinya secara konsisten berbicara positif mengenai organisasi dimana ia bekerja kepada rekan sekerja, calon karyawan yang potensial dan juga kepada pelanggan. Stay, maksudnya memiliki keinginan untuk menjadi anggota organisasi dimana ia bekerja dibandingkan kesempatan bekerja di organisasi lain. Dan, strive, memliki pengertian memberikan waktu yang lebih, tenaga dan inisiatif untuk dapat berkontribusi pada kesuksesan bisnis organisasi.

2. Aspek dan Dimensi Employee Engagement

Menurut Schaufeli dan Bakker (2003), terdapat tiga aspek yang membangun dimensi employee engagement, yaitu sebagai berikut:

a. Kekuatan (Vigor)

Kekuatan dikarakteristikkan dengan energi dan resiliensi (kemampuan beradaptasi dan keteguhan) mental yang tinggi ketika sedang bekerja, kemauan berusaha sungguh-sungguh dalam pekerjaan dan gigih dalam menghadapi kesulitan. Individu dengan skor tinggi pada aspek kekuatan biasanya memiliki energi dan stamina tinggi serta bersemangat ketika bekerja. Sedangkan individu dengan skor rendah pada aspek kekuatan memiliki tingkat energi, semangat dan stamina yang rendah saat bekerja.

\section{b. Dedikasi (Dedication)}

Dedikasi mengacu pada perasaan yang penuh makna, antusias, inspirasi, kebanggaan dan tantangan. Individu yang memiliki skor tinggi pada aspek dedikasi secara kuat mengidentifikasi diri dengan pekerjaan karena adanya pengalaman bermakna, menginspirasi dan menantang.
Selain itu, mereka selalu antusias dan bangga dengan pekerjaannya. Sedangkan individu dengan skor rendah tidak mengidentifikasi diri dengan pekerjaannya karena tidak memiliki pengalaman yang bermakna, menginspirasi dan menantang.

c. Keasyikan (Absorption) Absorpsi atau keasyikan dikarakteristikkan dengan konsentrasi penuh, minat terhadap pekerjaan dan sulit melepaskan diri dari pekerjaan. Individu yang memiliki skor tinggi pada aspek absorpsi biasanya merasa tertarik dengan pekerjaan dan sulit untuk melepaskan diri dari pekerjaannya, begitupun sebaliknya.

3. Tingkatan Employee Engagement Menurut Gallup (2004), terdapat tiga tingkatan engegement pada karyawan, yaitu:

a. Engaged. Karyawan yang engaged adalah seorang pembangun (builder). Mereka selalu menunjukkan kinerja dengan level yang tinggi. Karyawan ini akan bersedia menggunakan bakat dan kekuatan mereka dalam bekerja setiap hari serta selalu bekerja dengan gairah dan selalu mengembangkan inovasi agar perusahaan berkembang.

b. Not Engaged. Karyawan dalam tipe ini cenderung fokus terhadap tugas dibandingkan untuk mencapai tujuan dari pekerjaan itu. Mereka selalu menunggu perintah dan cenderung merasa kontribusi mereka diabaikan.

c. Actively Disengaged. Karyawan tipe ini adalah penunggu gua (cave dweller). Mereka secara konsisten menunjukkan perlawanan pada semua aspek. Mereka hanya melihat sisi negatif pada 
berbagai kesempatan dan setiap harinya, tipe actively disengaged ini melemahkan apa yang dilakukan oleh pekerja yang engaged.

Berdasarkan uraian tersebut, maka dalam penelitian ini aspek-aspek employee engagement yang digunakan adalah aspek employee engagement model Schaufeli dan Bakker, yaitu Kekuatan (Vigor), Dedikasi (Dedication), dan Keasyikan (Absorption).

\section{METODE}

\section{Hipotesis}

Berdasarkan permasalahan penelitian dan telaah teoritis/kerangka berfikir yang telah diuraikan pada bab terdahulu, maka secara rinci sebagai hipotesis adalah.:

$\mathrm{H}_{1}$ : Ada pengaruh gaya komunikasi pimpinan terhadap engagement karyawan generasi millenial di Badan Pendidikan dan Pelatihan Keuangan.

$\mathrm{H}_{2}$ : Ada pengaruh iklim organisasi terhadap engagement pegawai generasi millennial di Badan Pendidikan dan Pelatihan Keuangan.

$\mathrm{H}_{3}$ : Ada Pengaruh gaya komunikasi pimpinan dan iklim organisasi berpengaruh terhadap engagement pegawai generasi millennial di Badan Pendidikan dan Pelatihan Keuangan.

$\mathrm{H}_{4}$ : Ada pengaruh gaya komunikasi pimpinan terhadap iklim organisasi di Badan Pendidikan dan Pelatihan Keuangan.

\section{Variabel-variabel penelitian}

Dalam penelitian yang menjadi variabel penelitan adalah:

1. Variabel Terikat Engagement Pegawai Generasi Millenial

2. Variabel Bebas

Gaya Komunikasi Pimpinan, Iklim Organisasi

\section{Definisi operasional variabel} penelitian

1. Dalam penelitian ini aspek-aspek employee engagement diukur dengan skala employee engagement berdasarkan aspek employee engagement model Schaufeli dan Bakker, yaitu Kekuatan (Vigor), Dedikasi (Dedication), dan Keasyikan (Absorption).

2. Dalam penelitian ini gaya komunikasi pimpinan diukur dengan skala gaya komunikasi pimpinan berdasarkan aspekaspek gaya komunikasi pimpinan menurut model Tubbs, Stewart L \& Sylvia Moss yaitu gaya komunikasi mengendalikan (the controlling style), gaya komunikasi berlandaskan kesamaan (the equalitarian style), gaya komunikasi terstruktur (the structuring style), gaya komunikasi dinamis satu arah (the dynamic style), gaya komunikasi yang cenderung mau mendengarkan masukan (the relinguishing style), dan gaya komunikasi yang cenderung melepaskan diri dari tanggung jawab (the withdrawal style).

3. Dalam penelitian ini, iklim organisasi diukur dengan skala iklim organisasi berdasarkan aspek-aspek iklim organisasi menurut model Pines (1982) yaitu psikologikal, struktural, sosial dan birokratikal.

\section{Populasi dan Teknik Pengambilan} Sampel

1. Populasi

Sebagai populasi dalam penelitian ini adalah pegawai Badan Pendidikan dan Pelatihan Keuangan (BPPK) yang masuk dalam kategori generasi millenial. Survei akan dilakukan terhadap sampel secara acak.

2. Sampel

Sampel dalam penelitian ini adalah pegawai BPPK di seluruh Indonesia. Kriteria sampel dalam penelitian ini adalah pegawai dengan kelahiran antara tahun 1980 sampai dengan 1996, serta sudah bekerja di kantor yang sekarang sekurang-kurangnya 2 tahun.

3. Teknik Pengambilan Sampel 
Dalam penelitian ini, untuk menentukan ukuran sampel dari populasi digunakan tabel Krejcie dan Morgan (1970). Pengambilan sampel dilakukan secara purposive sampling yang merupakan cara pengambilan sampel berdasarkan pertimbangan atau kriteria tertentu.

\section{Pengumpulam data}

Penelitian berlangsung dari tanggal 17 Juli sampai dengan 31 Agustus 2018. Skala diberikan oleh para koordinator penelitian yang berada di kantor-kantor yang dipilih sebagai sampel. Untuk memudahkan dan mempercepat proses pengambilan data, penelitian ini memanfaatkan teknologi informasi menggunakan vasilitas google form, sehingga hasilnya langsung bisa didapatkan sesaat setelah responden melakukan input jawaban.

\section{HASIL DAN PEMBAHASAN}

\section{c. Analisis Data}

Uji Validitas

Uji validitas (keabsahan) dan reliabilitas (keandalan) dari alat ukur yang digunakan dalam penelitian inidapat diketahui dari kuesioner gaya komunikasi pimpinan dan iklim organisasi terhadap engagement pegawai, untuk memastikan bahwa seluruh item pernyataan yang digunakan dalam penelitian ini memiliki konsistensi internal untuk mengukur aspek yang sama dalam kuesioner. Pengujian validitas dilakukan pada penelitian ini mengunakan corrected item-total correlation, menurut Priyatno (2011) Metode corrected item-total correlation dengan cara mengkorelasikan masing-masing skor total item dan melakukan koreksi terhadap nilai koefisien korelasi yang overestimasi (estimasi nilai lebih tinggi dengan sebenarnya). Nilai validitas dihitung dengan nilai $r_{\text {tabel }}$ untuk $\alpha=$ 0,05 dengan $N$ (Responden) $=30$. Setelah dibandingkan dengan Corrected Item Total Correlation > $r_{\text {tabel. }}$.

Uji validitas pada kuesioner gaya komunikasi pimpinan terdiri dari 20 pertanyaan yang valid dan 4 pertanyaan yang tidak valid. Selanjutnya untuk luesioner iklim organisasi terdiri dari 17 pertanyaan yang valid dan 6 pertanyaan yang tidak valid dan kuesioner pada engagement pegawai terdiri dari 25 pertanyaan yang valid dan 6 pertanyaan yang tidak valid.

\section{b. Uji Reliabilitas}

Uji reliabilitas (keandalan) juga dilakukan pada kedua variabel bebas maupun variabel tergantung. Dari hasil uji validitas, item-item pernyataan dan indikator yang dinyatakan valid diukur reliabilitasnya atau keandalannya dengan bantuan program SPSS ver. 18.0 for Windows. Begitu pula pendapat secara teori menurut Priyatno (2011) Untuk menentukan apakah instrumen tersebut reliabel atau tidak, bisa digunakan batasan tertentu seperti 0,6 . Reliabilitas apabila kurang dari 0,6 adalah kurang baik, sedangkan 0,7 dapat diterima dan di atas 0,8 adalah baik. Hasil pengukuran reliabilitas ditunjukkan pada tebel di bawah ini. Berdasarkan perhitungan dengan olahan data statistik SPSS yang terlihat pada lampiran, diperoleh hasil -hasil reliabilitas untuk masingmasing variabel seperti pada tabel 11 berikut ini. 
Tabel 1.Uji Reliabilitas

\begin{tabular}{llcccl}
\hline No. & \multicolumn{1}{c}{ Variabel } & $\begin{array}{c}\text { Cronbach's } \\
\text { Alpha }\end{array}$ & rkritis & Ket \\
\hline 1 & Iklim Organisasi (X1) & 0.959 & 0.6 & Reliabel \\
2 & Gaya Komunikasi Pimpinan $(\mathrm{X} 2)$ & 0.974 & 0.6 & Reliabel & \\
3 & Engagement Pegawai $(\mathrm{Y})$ & 0.983 & 0.6 & Reliabel & \\
\hline
\end{tabular}

Nilai Cronbach's Alpha yang diperoleh adalah variabel Iklim Organisasi menunjukkan $r_{\text {alpa }}$ 0,959, variabel Gaya Komunikasi Pimpinan menunjukkan $r_{\text {alpa }}$ 0,974, variabel Engagement Pegawai menunjukkan $r_{\text {alpa }}$ 0,983. Dengan demikian karena nilai ini lebih besar dari batasan 0,6 , maka ketiga variabel ini dapat dinyatakan reliabel.

\section{Uji Normalitas}

$\begin{array}{lcr}\text { Menurut } & \text { Priyatno } & (2011) \\ \text { Pengujian } & \text { normalitas } & \text { data } \\ \text { menggunakan uji Kolmogorov- } & \text { uji } & \text { Kmirnov One Sample Test. Menurut } \\ \text { cara untuk mendeteksi normalitas }\end{array}$

yaitu uji normalitas KolmogorovSmirnov One Sample Test dengan melihat nilai signifikansi residual, dengan melihat dari angka probabilitasnya, dimana jika probabilitas > 0,05 maka residual terdistribusi normal. Sebaliknya jika probabilitas < 0,05 maka tidak berdistribusi normal Uji normalitas data dengan Kolmogorov-Smirnov One Sample Test dilakukan untuk melihat apakah keseluruhan variabel normal atau tidak. Berdasarkan hasil SPSS 18.00 menunjukkan bahwa uji normalitas seperti pada Gambar 1.

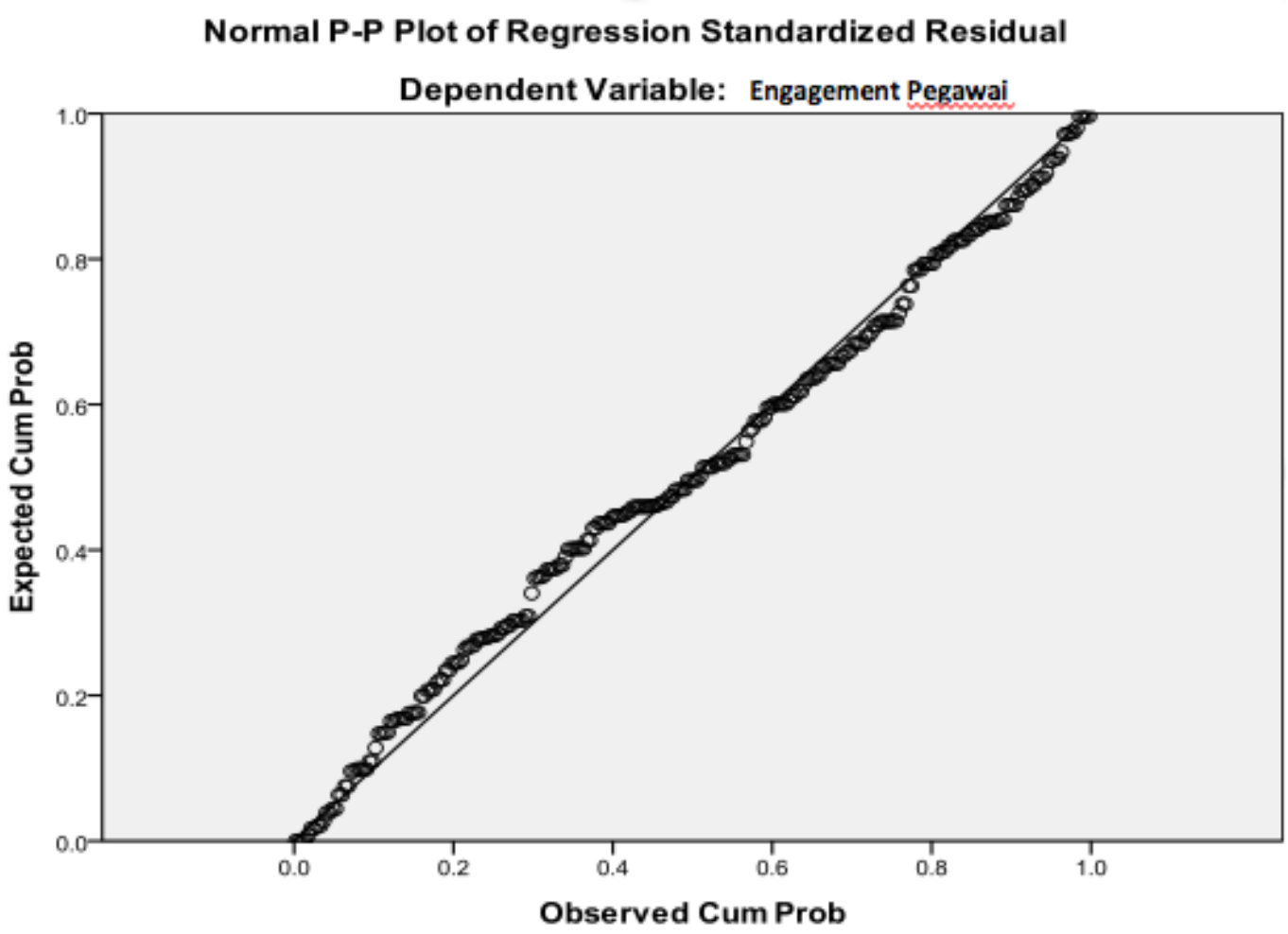

\section{Analisis Koefisien Korelasi}

Analisis korelasi ini digunakan untuk mengetahui tingkat (derajat) keeratan hubungan antara variabel bebas dengan variabel terikat, semakin besar korelasi maka semakin kuat hubungannya.
Normalitas Data

a. Korelasi Iklim Organisasi dengan Engagement Pegawai

Berikut ini adalah hasil perhitungan analisis korelasi Iklim Organisasi dengan Engagement Pegawai yang telah dianalisis 
menggunakan bantuan program SPSS 18.00. Berdasarkan perhitungan korelasi antara Iklim Organisasi dengan Engagement Pegawai diperoleh $r$ sebesar 0,564. Dari hasil tersebut, tampak bahwa Iklim Organisasi dengan Engagement Pegawai adalah sangat kuat dan searah (positif).

\section{b. Korelasi Gaya Komunikasi Pimpinan dengan Engagement Pegawai}

Berikut ini adalah hasil perhitungan analisis korelasi Gaya Komunikasi Pimpinan dengan Engagement Pegawai yang telah di analisis menggunakan bantuan program SPSS 18.00. perhitungan korelasi antara Gaya Komunikasi Pimpinan dengan Engagement Pegawai diperoleh $r$ sebesar 0,622. Dari hasil tersebut, tampak bahwa Gaya Komunikasi Pimpinan dengan Engagement Pegawai adalah sangat kuat dan searah (positif).

c. Korelasi Gaya Komunikasi Pimpinan, Iklim Organisasi dengan Engagemen Pegawai

Berikut ini adalah hasil perhitungan analisis korelasi Gaya Komunikasi
Pimpinan dan Iklim Organisasi dengan Engagement Pegawai yang telah dianalisis menggunakan bantuan program SPSS 18.00. Berdasarkan perhitungan korelasi antara Iklim Organisasi, Gaya Komunikasi Pimpinan dengan Engagement diperoleh $r$ sebesar 0,935. Dari hasil tersebut, tampak bahwa Iklim Organisasi, Gaya Komunikasi Pimpinan dengan Engagement Pegawai adalah sangat kuat dan searah (positif).

4. Analisis Regresi Model

\section{a. Analisis Regresi Model Struktural (Berganda)}

Menurut (Priyatno, 2011) analisis regresi linier berganda digunakan untuk mengetahui pengaruh antara dua variabel atau lebih variabel independen dan satu variabel dependen yang ditampilkan dalam bentuk persamaan regresi. Variabel independen dilambangkan dengan $\mathrm{X} 1, \mathrm{X} 2, \mathrm{X} 3 \ldots$. $\mathrm{Xn}$ sedangkan variabel dependen dilambangkan dengan Y. Pada tabel di bawah ini adalah hasil analisis regresi linier berganda. Hasil perhitungan regresi linier sederhana dengan menggunakan SPSS 18 dapat dilihat seperti pada tabel 2 di bawah ini.

Tabel 2. Hasil Persamaan Regresi Model Struktural

\begin{tabular}{|c|c|c|c|c|c|}
\hline \multicolumn{6}{|c|}{ Coefficients $^{a}$} \\
\hline \multirow[t]{2}{*}{$\overline{\text { Model }}$} & Unstandardized C & Coefficients & $\begin{array}{l}\text { Standardized } \\
\text { Coefficients }\end{array}$ & & \\
\hline & B & Std. Error & Beta & $t$ & Sig. \\
\hline 1 (Constant) & 8.497 & 2.316 & & 3.669 & .000 \\
\hline $\begin{array}{l}\text { Gaya Komunikasi } \\
\text { Pimpinan }\end{array}$ & .0514 & 209 & .338 & 2.458 & .015 \\
\hline Iklim Organisasi & 1.083 & .248 & 601 & 4.373 & .000 \\
\hline
\end{tabular}

\section{a. Dependent Variable: Engagement Pegawai}

Untuk membuat persamaan garis regresi dapat dilihat dari kolom $B$.

Constant $=$ 8.497, dimana Gaya Komunikasi Pimpinan $=0.514$ dan Iklim Organisasi $=1.083$. Dengan demikian persamaan garisnya adalah :

$\mathrm{Y}=8.497+0.514$ Gaya Komunikasi

Pimpinan + 1.083 Iklim Organisasi
1) Konstanta sebesar 8.497 menyatakan bahwa jika tidak ada Gaya Komunikasi Pimpinan dan Iklim Organisasi maka pengaruh terhadap Engagement Pegawai adalah sebesar 8.497.

2) Koefisien Gaya Komunikasi Pimpinan $=0.514$, menunjukkan bahwa Gaya Komunikasi Pimpinan berpengaruh positif terhadap Engagement Pegawai. Artinya, jika Gaya 
Komunikasi Pimpinan ditingkatkan sebesar satu satuan, maka peningkatan Engagement Pegawai akan meningkat sebesar 0.514 .

3) Koefisien Iklim Organisasi $=1.083$, menunjukkan bahwa Iklim Organisasi berpengaruh positif terhadap Engagement Pegawai. Artinya, jika Iklim Organisasi ditingkatkan sebesar satu satuan, maka peningkatan Engagement Pegawai akan meningkat sebesar 1.083 .

4) Standar error (e) menunjukkan tingkat kesalahan pengganggu.

Hasil regresi linier ganda di atas menunjukkan bahwa variabel Gaya Komunikasi Pimpinan dan Iklim Organisasi memiliki pengaruh positif terhadap variabel Engagement Pegawai. Dengan demikian dapat ditarik kesimpulan bahwa, jika Gaya Komunikasi Pimpinan dan Iklim Organisasi ditingkatkan maka Engagement Pegawai juga akan meningkat.

\section{b. Uji Hipotesis}

1. Uji Signifikansi Simultan (Uji Statistik F)

Menurut (Priyatno, 2011) uji $F$ digunakan untuk menguji pengaruh semua variabel independen atau variabel bebas secara bersama-sama terhadap variabel dependen atau variabel terikat. Kriteria pengambilan keputusannya adalah bila $\mathrm{F}$ hitung $>\mathrm{F}$ tabel maka Ho ditolak dan menerima $\mathrm{Ha}$ (Ghozali, 2005,84). Hasil uji F dalam penelitian ini dapat dilihat seperti pada tabel 3 dan berikut.

Tabel 3. Hasil Uji Simultan Model Struktural

\begin{tabular}{|c|c|c|c|c|c|c|}
\hline \multirow{2}{*}{$\overline{\text { Model }}$} & \multicolumn{6}{|c|}{$A_{N O V A}^{b}$} \\
\hline & & $\begin{array}{l}\text { Sum of } \\
\text { Squares }\end{array}$ & $D f$ & Mean Square & $\mathrm{F}$ & Sig. \\
\hline 1 & Regression & 81487.241 & 2 & 40743.621 & 896.839 & $.000^{\mathrm{a}}$ \\
\hline & Residual & 11675.570 & 257 & 45.430 & & \\
\hline & Total & 93162.812 & 259 & & & \\
\hline
\end{tabular}

a. Predictors: (Constant), Gaya Komunikasi Pimpinan, Iklim Organisasi

b. Dependent Variable: Engagement Pegawai

Berdasarkan data table 3, bahwa nilai $F$ berada pada signifikansi 0,000 yang berarti $<0,05$. Dengan demikian secara bersama-sama Gaya Komunikasi Pimpinan dan Iklim Organisasi berpengaruh nyata terhadap Engagement Pegawai. Hipotesis yang diujikan yang menyatakan bahwa Gaya Komunikasi Pimpinan dan Iklim Organisasi berpengaruh positif dan nyata terhadap Engagement Pegawai dapat diterima.

\section{Uji Signifikansi Parameter Individual (Uji Statistik t)}

Uji statistik $t$ dilakukan untuk menunjukkan seberapa jauh satu variabel independen secara individual dalam menerangkan variabel dependen (Ghazali,2011). Hasil pengujian parsial tersebut dapat dilihat pada tabel 4 di bawah ini

Tabel 4. Hasil Pengujian Parsial (Uji t) Model Struktural Coefficients $^{a}$

\begin{tabular}{llrrrrr}
\hline Model & \multicolumn{7}{c}{ Standardized } \\
& \multicolumn{7}{c}{ Unstandardized Coefficients } & Coefficients & & \\
\cline { 2 - 5 } & $B$ & Std. Error & Beta & & \multicolumn{1}{c}{ Sig. } \\
\hline 1 & (Constant) & 8.497 & 2.316 & & 3.669 & .000 \\
& Gaya Komunikasi & .514 & .209 & .338 & 2.458 & .015 \\
& $\begin{array}{l}\text { Pimpinan } \\
\text { Iklim Organisasi }\end{array}$ & 1.083 & .248 & .601 & 4.373 & .000 \\
\hline
\end{tabular}

a. Dependent Variable: Engagement Pegawai 
Berdasarkan hasil pengujian parsial (uji t) Model Struktural 1 pada tabel 4, diketahui bahwa :

a. Pengujian Parsial Gaya Komunikasi Pimpinan terhadap Engagement Pegawai memperlihatkan bahwa Variabel Gaya Komunikasi Pimpinan mempunyai nilai sig sebesar 0.015, yang kemudian dibandingkan dengan probabilitas 0.05 , ternyata nilai probabilitas Sig lebih kecil dari nilai probabilitas $0.05(0.015<0.05)$. Terbukti bahwa ada pengaruh kontribusi antara variabel Gaya Komunikasi Pimpinan secara signifikan terhadap Engagement Pegawai dalam penelitian ini. b. Pengujian Parsial Iklim Organisasi terhadap Engagement Pegawai menggambarkan bahwa Variabel Iklim Organisasi mempunyai nilai sig sebesar 0.000, yang kemudian dibandingkan dengan probabilitas 0.05 , ternyata nilai probabilitas Sig lebih kecil dari nilai probabilitas 0.05 $(0.000<0.05)$. Terbukti bahwa ada pengaruh kontribusi antara variabel Iklim Organisasi secara signifikan terhadap Engagement Pegawai dalam penelitian ini.

c. Analisis Struktural jalur Path

Koefisien jalur dihitung dengan cara membuat dua persamaan struktural yaitu :

Tabel 5. Analisis Struktural Jalur Path untuk Engagement Pegawai

\begin{tabular}{|c|c|c|c|c|c|c|}
\hline \multicolumn{7}{|c|}{ Coefficients $^{a}$ Struktural } \\
\hline \multirow{3}{*}{\multicolumn{2}{|c|}{ Model }} & & & \multicolumn{3}{|l|}{ Standardized } \\
\hline & & \multicolumn{2}{|c|}{ Unstandardized Coefficients } & Coefficients & \multirow[b]{2}{*}{$t$} & \multirow[b]{2}{*}{ Sig. } \\
\hline & & $B$ & Std. Error & Beta & & \\
\hline 1 & (Constant) & 8.497 & 2.316 & & 3.669 & .000 \\
\hline & $\begin{array}{l}\text { Gaya Komunikasi } \\
\text { Pimpinan }\end{array}$ & .514 & .209 & .338 & 2.458 & .015 \\
\hline & Iklim Organisasi & 1.083 & .248 & .601 & 4.373 & .000 \\
\hline
\end{tabular}

a. Dependent Variable: Engagement Pegawai

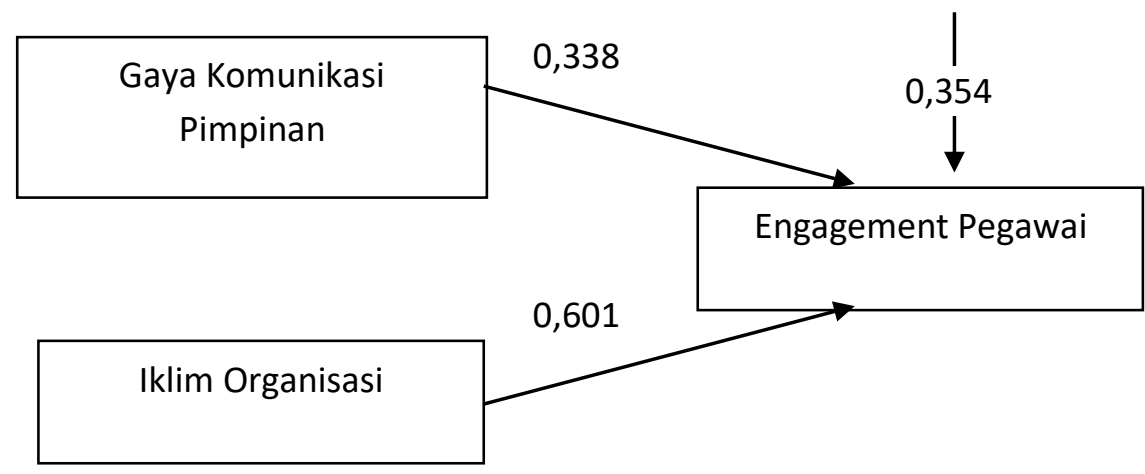

Gambar 2 : Hasil Analisis Struktural

Model Struktural : $\mathrm{Y}_{\mathrm{CA}}=0,338 \mathrm{GKT}+$ $0,601 \mathrm{IO}+0,752$

Model ini signifikan karena $p$-value $=$ 0,000 lebih kecil dari $\alpha$

Koefisien jalur :

$\mathrm{X} 1=0,338$,

karena $p$-value $=0,015$ lebih kecil dari $\alpha$,

koefisien jalur ini signifikan

$\mathrm{X} 2=0,601$, karena $p$-value $=0,000$ lebih kecil dari $\alpha$, koefisien jalur ini signifikan

$\mathrm{px3}=\sqrt{1-R^{2}}=\sqrt{1-0,875}=0,354$.

Berdasarkan hasil di atas, diperoleh koefisien jalur px3 yaitu 0,354. 


\section{d. Koefisien Determinasi}

Menurut Priyatno (2011) analisis determiansi digunakan untuk mengetahui presentase sumbangan pengaruh variabel independen secara bersama-sama terhadap variabel dependen. Hasil analisis determinasi dapat dilihat pada output model Model Summary dari hasil analisis regresi linier berganda. Untuk pengukuran digunakan Adjusted $\mathrm{R}^{2}$ sebagai koefisien determinasi.

Uji ini bertujuan untuk mengukur seberapa besar variasi dari variabel independen dapat menjelaskan variabel dependen. Kelemahan mendasar penggunaan koefisien determinasi adalah bias terhadap jumlah variabel independen yang dimasukkan kedalam model. Banyak peneliti menganjurkan untuk menggunakan nilai Adjusted $R^{2}$ pada saat mengevaluasi mana model regresi terbaik karena nilai Adjusted $R^{2}$ dapat naik atau turun apabila suatu variabel independen ditambahkan kedalam model.

Analisis koefisien determinasi Model Struktural dilakukan untuk mengukur seberapa jauh kemampuan model dalam menerangkan variabel Iklim Organisasi dan Gaya Komunikasi Pimpinan terhadap Engagement Pegawai seperti pada table 6 .

\section{Tabel 6. Hasil Uji Koefisien Determinasi Model Struktural Model Summary ${ }^{b}$ Struktural 1

\begin{tabular}{lrrrr}
\hline Model & $R$ & $R$ Square & $\begin{array}{c}\text { Adjusted } R \\
\text { Square }\end{array}$ & $\begin{array}{c}\text { Std. Error of } \\
\text { the Estimate }\end{array}$ \\
\hline 1 & $.935^{\text {a }}$ & .875 & .874 & 6.740 \\
\hline
\end{tabular} \\ a. Predictors: (Constant), Gaya Komunikasi Pimpinan, Iklim \\ Organisasi \\ b. Dependent Variable: Engagement Pegawai}

Dengan melihat dari tabel di atas hasil perhitungan di atas di mana $R$ square sebesar 0,875 atau $87,5 \%$. Hal ini menunjukkan besarnya kontribusi dari Gaya Komunikasi Pimpinan dan Iklim Organisasi terhadap Engagement Pegawai sebesar $87,5 \%$ sedangkan sisanya $22,5 \%$ merupakan kontribusi faktor lain yang tidak diteliti dalam penelitian ini.

\section{KESIMPULAN}

Analisis melalui model jalur struktural path sebenarnya mampu diterapkan di organisasi, karena antar variabel memiliki hubungan dan juga pengaruh yang signifikan baik secara simultan maupun parsial pada aktivitas akhir yang ingin dicapai. Maka kesimpulan penelitian ini adalah sebagai berikut:

1. Ada pengaruh gaya komunikasi pimpinan dan iklim organisasi terhadap engagement pegawai pada Badan Pendidikan dan Pelatihan Keuangan.
2. Ada pengaruh gaya komunikasi pimpinan terhadap engagement pada Badan Pendidikan dan Pelatihan Keuangan.

3. Ada pengaruh iklim organisasi terhadap engagement pegawai pada Badan Pendidikan dan Pelatihan Keuangan.

\section{SARAN}

Dari penelitian yang telah dilakukan, penulis memberikan saran baik berupa saran teoretis maupun saran praktis. Saran penelitian adalah tersebut adalah sebagai berikut.

1. Saran Teoretis

Berdasarkan analisis tambahan pada sumbangan pengaruh setiap kategori pada masing-masing variabel, penulis menyarankan untuk peneliti selanjutnya dapat dilakukan terhadap faktor penempatan, mengingat Badan Pendidikan dan Pelatihan Keuangan tersebar di beberapa daerah di Indonesia, 
sementara mayoritas pegawainya berasal dari pulau Jawa.

2. Saran Praktis

Pimpinan Badan Pendidikan dan Pelatihan Keuangan agar terus mendorong terbentuk dan terjaganya sikap dan perilaku para pimpinan menyangkut gaya berkomunikasi dengan bawahan di level bawah (eselon 4) hingga atas (eselon 2). Sikap dan perilaku pimpinan yang mencerminkan gaya komunikasi informal lebih dikedepankan. Langkah-langkah untuk membentuk dan membiasakan para pemimpin dengan gaya komunkiasi informal yang bisa dilakukan adalah sebagai berikut.

a. Membekali para pimpinan kemampuan berkomunikasi interpersonal dengan bawahan, kemampuan memahami kebutuhan dan kesulitan bawahan dalam menjalankan tugas dan tanggung jawab pekerjaannya. Sehingga para bawahan dapat memberikan kontribusi terbaiknya kepada organisasi.

b. Membekali para pimpinan kemampuan membangun komitmen bersama dan memberikan kepercayaan kepada bawahan baik secara formal maupun informal untu menciptakan iklim organisasi tempat kerja yang baik.

\section{DAFTAR PUSTAKA}

BPPK. (2011). Per.002 tahun 2011 tentang Pedoman Kajian Akademis BPPK. Jakarta: BPPK.

Elmubarok, Z. (2009). Membumikan Pendidikan Nilai: Mengumpulkan yang Terserak, Menyambung yang Terputus dan Menyatukan yang Tercerai. Bandung: Alfabeta.

Furchon, A. (1982). Pengantar Penelitian dalam Pendidikan. Surabaya: Usaha Nasional.

Marcos, S dan Sridevi M. S. 2010. Employee Engagement: The Key to Improving
Performance. International Journal of Business and Management. Scientific Research. Vol (5):1, 89-96.

Muhidin, S. A. (2011). Panduan Praktis Memahami Penelitian. Bandung: Pustaka Setia.

Moleong, L. J. (2009). Metodologi Penelitia Kualitatif. Bandung: Remaja Rosdakarya.

Mulyana, R. (2011). Mengartikulasikan Pendidikan Nilai. Bandung: Alfabeta.

Poerwadarminta, W.J.S. (2006). Kamus Umum Bahasa Indonesia. Jakarta: Balai Pustaka.

Sugiyono. (2011). Penelitian Kuantitaif, Kualitatif dan $R \& D$. Jakarta: Alfabeta.

Sekretariat Negara. Undang-undang Republik Indonesia No. 25 Tahun 29. Jakarta: Sekretariat Negara.

Yadianto. (2000). Kamus Umum Bahasa Indonesia. Bandung: M2S.

Fitriyati. (n.d.). Fakultas Ushuluddin IAIN Walisongo. Retrieved Maret 22, 2016, from Aritikel: https://ushuluddinwalisongo.wordpress. com/artikel/kepribadian-dan-nilai/

Gani, P. K. (n.d.). Preta Kemal Gani. Retrieved Maret 22, 2016, from Pentingnya Nilai Budaya Bagi Organisasi: http://www.Ispr.edu/pritakemalgani/pent ingnya-nilai-budaya-bagi-organisasi/

Jamil, M. (n.d.). Kumpulan Tugas. Retrieved Maret 22, 2016, from NILAI DALAM PRILAKU ORGANISASI: http://jamillagilagi.blogspot.co.id/2013/0 4/15-nilai-dalam-prilaku-organisasi.html

Mubarok, A. Z. (2013, April 19). Perubahan Sosial. Retrieved Maret 22, 2016, from Nilai-nilai dan Kepribadian dalam Organisasi, Masyarakat dan Pendidikan:

http://zackeyhernandez.blogspot.co.id/ 2013/04/nilai-nilai-dan-kepribadiandalam.html

Rahardjo, M. (n.d.). Trianggulasi Dalam Penelitian Kualitatif. Retrieved Maret 22, 2016, from Mudjiarahardjo: http://mudjiarahardjo.com/artikel/270.ht m?task=view

Udiutomo, P. (n.d.). Pancasila dan Pendidikan Karakter. http://purwoudiutomo.com/tag/indoktrin asi/ 